\title{
A CONCEPTUAL FRAMEWORK FOR QUALITATIVE RESEARCH: A LITERATURE STUDIES
}

\author{
Guntur $^{1}$ \\ ${ }^{1}$ Insitut Seni Indonesia (ISI) Surakarta \\ E-mail: gunturisi@yahoo.co.id
}

\begin{abstract}
The conceptual framework is an important part of a research. However, there is still a lot of research, especially among students who ignore it. Indeed the conceptual framework has a strategic position and role in research. This article discusses about the conceptual framework in qualitative research. Specifically, it is aimed at providing understanding and practical guidance for students who will and / or are preparing research plans for their final assignments. This article consists of four main section / part. The first section discusses the understanding of research and research frameworks. The second section discusses the conceptual framework in qualitative research. The third section discusses how to develop / arrange a conceptual framework for qualitative research. The final chapter is a conclusion.
\end{abstract}

Keywords: framework, conceptual framework, and qualitative research

\section{ABSTRAK}

Kerangka konseptual merupakan bagian penting dari sebuah penelitian, tetapi masih banyak penelitian, khususnya di kalangan mahasiswa, yang mengabaikannya. Sesungguhnya kerangka kerja konseptual memiliki kedudukan dan peran strategis dalam penelitian. Artikel ini membahas tentang kerangka konseptual dalam penelitian kualitatif, secara khusus ditujukan untuk memberikan pemahaman dan panduan praktis bagi mahasiswa yang akan dan/atau sedang menyusun rencana penelitian untuk tugas akhir studinya. Artikel ini terdiri dari empat bagian pokok. Bagian pertama membahas tentang pengertian penelitian dan kerangka kerja penelitian. Bagian kedua membahas tentang kerangka konseptual dalam penelitian kualitatif. Bagian ketiga membahas tentang cara menyusun kerangka kerja konseptual penelitian kualitatif. Bagian akhir merupakan kesimpulan.

Kata kunci: kerangka kerja, kerangka konseptual, dan penelitian kualitatif

\section{PENDAHULUAN}

Perguruan tinggi seni memiliki dua model tugas akhir untuk memfasilitasi penyelesaian studi mahasiswa, yakni berbasis karya ilmiah dan berbasis karya seni. Model pertama dilakukan melalui penelitian untuk jenjang sarjana dalam bentuk skripsi, jenjang magister dalam bentuk tesis, dan jenjang doktoral dalam bentuk disertasi. Model kedua $\square$ karya seni juga dilakukan melalui penelitian, yakni penelitian artistik, untuk menghasilkan karya seni dan laporan deskripsi karya atau portofolio (Guntur, 2016). Model mana yang dipilih bergantung pada minat mahasiswa dan persyaratan lain yang ditetapkan oleh perguruan tinggi.

Penelitian untuk tugas akhir mahasiswa biasanya didampingi oleh dosen pembimbing untuk jenjang sarjana dan magister dan tim promotor untuk jenjang doktoral. Pembimbing atau tim 
promotor bertindak sebagai konsultan atau supervisor dalam memfasilitasi rencana, pelaksanaan, dan hasil penelitian. Kehadiran pembimbing dan tim promotor diharapkan dapat mempercepat penyelesaian tepat waktu dan meningkatkan mutu penelitian skripsi, tesis, dan doktor.

Pada beberapa kasus menunjukkan bahwa tugas akhir penelitian mahasiswa di lingkungan perguruan tinggi seni tidak dapat selesai tepat waktu. Selain itu kualitas penelitian juga masih perlu ditingkatkan. Dasar-dasar penelitian yang disediakan matakuliah metode penelitian dan diseminasi pemikiran melalui matakuliah seminar belum sepenuhnya berkontribusi terhadap persoalan penelitian yang dihadapi mahasiswa. Pengalaman penulis dalam membimbing, menelaah, serta menguji hasil penelitian mahasiswa menunjukkan bahwa mahasiswa sebagai besar belum memahami kedudukan dan peran kerangka kerja konseptual dalam penelitiannya.

Kerangka kerja konseptual, yang selanjutnya disebut kerangka konseptual, masih dianggap sebagai sumber permasalahan dalam penelitian mahasiswa. Mahasiswa dalam berbagai kesempatan menanyakan tentang "apa kerangka konseptual?", "mengapa kerangka konseptual harus ada dalam sebuah penelitian?", atau "bagaimana penerapan kerangka konseptual dalam penelitian?" Sebaliknya, dosen pembimbing skripsi, tesis, dan/atau disertasi hampir selalu menanyakan kepada mahasiswa bimbingannya tentang "apa kerangka konseptual penelitian saudara?"

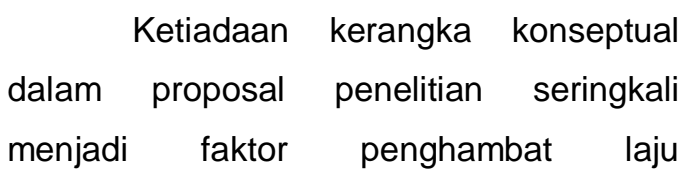
penyelesaian studi dan mutu penelitian mahasiswa. Ketiadaan kerangka konseptual penelitian berakibat penolakan oleh dosen pembimbing yang berujung pada penundaan ujian kelayakan proposal penelitian, ujian kelayakan hasil penelitian, dan ujian akhir hasil penelitian mahasiswa. Kerangka konseptual penelitian tidak hanya berpengaruh terhadap masa penyelesaian studi, tetapi yang jauh lebih penting lagi adalah kualitas penelitian.

Berdasar pemikiran di atas, maka timbul pertanyaan "apa kerangka konseptual penelitian?", “mengapa kerangka konseptual harus ada dalam penelitian?", "bagaimana menyusun kerangka konseptual?".

Artikel ini tidak dimaksudkan untuk mengatasi seluruh problematika penelitian, melainkan sebagai upaya membantu mengatasi salah satu permasalahan dalam penelitian yang dihadapi mahasiswa, khususnya terkait kerangka konseptual. Meski demikian bukan berarti permasalahan ini tidak dianggap penting. Justru sebaliknya, kerangka konseptual memiliki kedudukan sentral dalam 
penelitian, baik dalam penyusunan rencana, pelaksanaan, dan temuan yang diharapkan sebagai hasil penelitian.

\section{TINJAUAN PUSTAKA}

Kerangka konseptual penelitian telah lama menjadi perhatian dan pemikiran para sarjana. Melalui berbagai publikasi, khususnya buku yang telah diterbitkan, kita mengetahui tentang pengertian, kedudukan, dan peran kerangka konseptual dalam penelitian. Berikut adalah tinjauan tentang kerangka konseptual yang telah dirumuskan oleh para sarjana.

Miles dan Huberman (1994) dalam Qualitative Data Analysis menyatakan bahwa meski kerangka konseptual sangat berguna dalam menentukan pengumpulan data, menentukan mana yang penting dan tidak. Kerangka konseptual terkait dengan konseptualisasi penelitian.

Anselm L. Strauss dan Juliet M. Corbin (1998) dalam Basics of Qualitative Research: Techniques and Procedures for Developing Grounded Theory menyatakan bahwa kerangka konseptual penting dalam pengumpulan dan analisis data bagi setiap anggota penelitian kelompok, bahkan kerangka konseptual juga digunakan untuk mengembangkan teori.

S. B. Merriam (1998) dalam Qualitative Research and Case Study Applications in Education menyatakan bahwa betapa sulit dibayangkan jika penelitian kualitatif tanpa kerangka teoretis atau kerangka konseptual. Terlepas dari apakah dinyatakan secara eksplisit atau implisit, kerangka tersebut memiliki peran penting karena membimbing pelaksanaan penelitian. Kerangka penelitian adalah struktur, perancah, dan kerangka penelitian. Jonathan H. Turner (2001) dalam Handbook of Sociological Theory menyatakan bahwa kerangka konseptual dapat digunakan untuk memfasilitasi dan menjembatani pergerakan orang dan struktur sosial, memahami kehidupan sosial, menentukan variasi struktur sosial dan variasi pribadi sosial dan hubungan diantara berbagai variasi tersebut.

Klaus Krippendorff (2004) dalam Content Analysis: An Introduction to Its Methodology menyatakan bahwa kerangka konseptual merupakan tujuan dan proses analisis konten. Kerangka konseptual menyediakan tiga tujuan, yakni preskriptif, analisis, dan metodologis. Tujuan preskriptif untuk memandu konseptualisasi dan desain penelitian serta praktik analisis konten. Tujuan analitis untuk memfasilitasi penyelidikan kritis dan perbandingan analisis konten. Tujuan metodologis untuk menunjukkan kriteria kinerja dan standar kehati-hatian yang diterapkan peneliti dalam mengevaluasi analisis konten yang sedang berlangsung.

Kathleen deMarris dan Stephen D. Lapan (2004) dalam Foundation for Research: Methods of Inquiry in Education 
and the Social Sciences menyatakan bahwa kerangka konseptual merupakan bagian awal dari proses penelitian. Bahkan, bagi peneliti yang berpengalaman sekalipun kerangka konseptual penting karena mendasari seluruh proses penelitian. Tinjauan pustaka yang dilakukan peneliti tidak hanya semata-mata digunakan untuk memetakan topik penelitian, tetapi juga menjadi fondasi dalam menyusun kerangka konseptual.

Zina O'Leary (2004) dalam The Essential Guide to Doing Research menyatakan bahwa kerangka konseptual merupakan bagian integral antara apa yang diteliti dan temuan penelitian. Terdapat hubungan saling terkait antara kerangka konseptual, pertanyaan penelitian, dan bukti temuan penelitian. Kerangka konseptual menjadi bagian penting dari validitas dan autentisitas penelitian.

Bridget Somekh dan Cathy Lewin (2005) dalam Research Methods in the Social Sciences menyamakan kerangka konseptual dengan paradigma. Menurutnya, paradigma tidak lebih dari kerangka konseptual yang menyediakan model yang melaluinya memunculkan tradisi penelitian ilmiah yang koheren. Dalam hal ini digunakan untuk membangun kerangka konseptual yang digunakan untuk memandu menyusun pertanyaan dan metode penelitian.

John W. Creswell (2009) dalam Research Design: Qualitative, Quantitative, and Mixed Methods Approaches menyebutkan bahwa dalam penelitian kuantitatif sekalipun kerangka konseptual tetap diperlukan. Menurutnya, kerangka konseptual menjadi komponen utama untuk menyatakan tujuan kuantitatif. Pernyataan tujuan kuantitatif meliputi variabel penelitian dan keterhubungannya, partisipan, dan lokasi penelitian. pernyataan tujuan ini memberikan penekanan pada pentingnya teori yang digunakan dalam penelitian.

Biggs and Karlsson, Ed. (2011) The Routledge Companion to Research in the Arts menyatakan bahwa kerangka konseptual memainkan peran penting dalam proses penelitian berbasis praktik. Lebih lanjut dinyatakan bahwa kerangka konseptual memberikan informasi dan memandu pembuatan dan evaluasi artefak.

\section{METODE}

Penelitian ini merupakan penelitian kualitatif dengan pendekatan kepustakaan (library research method). Penelitian kepustakaan dilakukan dengan cara mengidentifikasi dan menempatkan berbagai sumber yang menyediakan informasi aktual atau opini pribadi/ahli tentang suatu pertanyaan penelitian (George, 2008:6).

Adapun proses penelitian dilakukan dengan tahapan sebagai berikut: (1) memilih topik umum, membayangkan pemecahan masalah, (3) curah-pendapat (brainstorming) tentang topik, (4) mengembangkan rencana atau 
strategi penelitian, (5) mencocokkan perangkat rujukan dan mencari basis data, (6) mengidentifikasi dan memperoleh sumber, (7) mengevaluasi sumber sesuai pertanyaan penelitian, (8) memiliki wawasan berdasar refleksi, dan (9) menyusun pernyataan berdasarkan wawasan (George, 2008:16).

Berdasar pemikiran Mary W. George tersebut, sekurang-kurangnya terdapat tiga hal pokok dalam penelitian kepustakaan, yakni: menemukan, sumber, dan piranti. Menemukan yang dimaksud dalam hal ini adalah menemukan fakta tentang, mengidentifikasi keberadaan dari, menempatkan, memperoleh, atau beberapa tindakan tersebut sekaligus. Sumber yang dimaksud adalah bukti jawaban penelitian yang berasal dari observasi atau opini. Piranti yang dimaksud adalah segala sumber pengetahuan. Dalam hal ini mencakup kamus, ensiklopedia, kalalog buku dan bahan lain baik cetak maupun elektronik (George, 2008:19-20).

Dalam penelitian ini informasi aktual tentang kerangka konseptual diidentifikasi melalui sumber yang berasal dari buku dan artikel ilmiah baik dari para ahli atau sarjana. Sumber yang membahas kerangka konseptual berasal dari 10 judul buku dan 10 judul. artikel ilmiah. Masingmasing sumber yang di dalamnya membahas topik tentang metode penelitian secara umum dan kerangka konseptual secara khusus. Sepuluh sumber buku metode penelitian membahas tentang: filsafat penelitian, pendekatan penelitian, manajemen penelitian, ensiklopedia, metode penelitian, panduan penelitian, teori, paradigma penelitian, dan penelitian kepustakaan. Sepuluh sumber yang berasal dari artikel ilmiah membahas tentang: kegunaan kerangka konseptual, kerangka teoretis, kerangkakerja penelitian, penulisan, paradigma, pendekatan, dan tinjauan pustaka.

Masing-masing dari sumber ditinjau, dievaluasi (Bowen, 2009:27-28), dan dianalisis terkait dengan: (1) penelitian, (2) pengertian kerangka konseptual, (3) peran kerangka konseptual bagi peneliti, (4) peran kerangka konseptual bagi penelitian, dan (5) penyusunan kerangka konseptual.

\section{PEMBAHASAN}

\subsection{Penelitian}

Banyak pengertian tentang penelitian. Penelitian adalah investigasi atau penyelidikan yang sistematis, terkontrol, empiris, dan kritis tentang fenomena sosial atau alam, dibimbing oleh teori dan hipotesis tentang relasi di antara fenomena itu (De Vos et.al., 2005:41).

Penelitian kualitatif adalah jenis penelitian yang hasil temuannya tidak dicapai melalui prosedur statistik atau sarana manipulasi lainnya, melainkan merujuk pada kehidupan orang, pengalaman hidup, perilaku, emosi, dan 
perasaan termasuk juga fungsi organisasi, gerakan sosial, fenomena budaya, dan interaksi antar negara (Strauss and Corbin, 1998:10-11). Penelitian kualitatif sangat relevan untuk mengkaji relasi sosial, yakni adanya pluralitas dunia kehidupan. Pluralitas ini memerlukan sensitivitas baru untuk mengkaji isu-isu empiris (Flick, 2010:12).

\subsection{Paradigma Penelitian Kualitatif}

Paradigma memiliki kedudukan dan peran sangat penting dalam setiap penelitian. Paradigma adalah seluruh konstelasi keyakinan, nilai, teknik, dan lainnya yang dibagi bersama oleh anggota dari suatu komunitas (Kuhn, 1970:115); sudut pandang (Patton, 1990:37); bagaimana dunia itu dipandang atau dikonsepsikan (Burrell and Morgan, 1979:24).

Penelitian yang baik memerlukan asumsi paradigma dan kerangka yang eksplisit dalam penelitian yang mempengaruhi pelaksanaan penelitian (Creswell, 2007:15). Seorang peneliti memerlukan paradigma, karena melaluinya akan membimbing investigasi atau penelitian (Guba and Lincoln, 1994:105).

Paradigma sebagai sistem keyakinan dasar berbasis pada asumsi ontologis, epistemologis, dan metodologis (Guba and Lincoln, 1994:107). Asumsi tersebut membentuk basis paradigma penelitian yang berbeda (Gray and Malins, 2004:19).

\subsection{Asumsi-asumsi Penelitian Kualitatif}

Asumsi ontologi adalah studi tentang "dunia seperti apa yang kita teliti, dengan sifat eksistensi, dengan struktur realitas seperti apa” (Cortty, 2003:10), "apa yang ada di sana yang dapat diketahui?" atau "apa bentuk dan sifat realitas?" dan "apa yang dapat diketahui tentangnya" (Guba dan Lincoln 1989:83; Guba dan Lincoln, 1995:108).

Asumsi epistemologi adalah "suatu cara memahami dan menjelaskan bagaimana kita mengetahui tentang apa yang kita ketahui" (Crotty, 2003:3), "sifat dan bentuk pengetahuan" (Cohen, Manion, and Morrison, 2007:7), "sifat relasi antara yang mengetahui (the knower)dan apa yang dapat diketahui (the known)" (Guba dan Lincoln, 1994:108).

Asumsi metodologi adalah tentang "bagaimana peneliti dapat menemukan apapun yang diyakini dapat diketahui?" Metodologi berkait dengan mengapa, apa, dari mana, kapan, dan bagaimana data dikumpulkan dan dianalisis (Guba dan Lincoln, 1994:108). Metodologi merujuk pada suatu prinsip teoretis atau prinsip membangun aplikasi seperangkat metode atau teori praktik metodis (Harrington, (Ed.), 2005:4-5), strategi atau rencana aksi atau desain dibalik metode tertentu yang dipilih dan yang digunakan serta terkait dengan pilihan dan penggunaan metode tersebut terhadap hasil yang diinginkan (Crotty, 2003:3). 


\subsection{Metode dan Langkah Penyusunan Kerangka Konseptual Penelitian}

Kerangka penelitian sangat penting dalam setiap bidang penelitian (Lester, 2005:458), karena merupakan struktur yang memandu peneliti terkait dengan pertanyaan, metode untuk mengukur dan menganalisis variabel penelitian (Liehr and Smith, 1999:13), menjadi dasar memahami pola sebab akibat atau korelasi interkoneksi berbagai peristiwa, ide, pengamatan, konsep, pengetahuan, interpretasi, dan komponen pengalaman lainnya (Svinicki, 2010:5).

Terdapat tiga jenis kerangka penelitian, yakni: (1) kerangka teoretis, (2) kerangka praktis, dan (3) kerangka konseptual. Kerangka teoretis disusun berdasar teori formal. Kerangka praktis disusun berdasar akumulasi pengetahuan praktis praktisi. Kerangka konseptual disusun berdasar konsep tertentu dan bermakna untuk mengantisipasi relasi konsep satu dengan konsep lainnya (Lester, 2005:458-459).

Kerangka penelitian memiliki empat fungsi, yakni: (1) sebagai struktur dalam mengkonseptualisasikan dan merancang penelitian; (2) memahami seperangkat data; (3) mentransendensikan akal sehat; dan (4) memahami lebih mendalam (Lester, 2005:458) atau untuk: (1) merumuskan permasalahan penelitian, (2) membangun koherensi teoretis, mengorganisasikan rencana dan implementasi penelitian, dan (4) mengkerangkakan simpulan konseptual (Berman, 2013:3).

Dalam berbagai pendekatan penelitian kualitatif, para peneliti menggunakan kerangka interpretif dan teoretis untuk membentuk konten penelitian. Penelitian yang baik membutuhkan asumsi, paradigma, dan kerangka penelitian secara eksplisit dan mempengaruhi pelaksanaan penelitian (Creswell,2007:15).

\subsection{Kedudukan dan Peran Kerangka Konseptual}

\subsubsection{Pengertian Kerangka Konseptual}

Kerangka konseptual adalah jejaring, yakni konsep saling terkait yang bersama-sama memberikan pemahaman komprehensif tentang suatu fenomena atau beberapa fenomena (Jabareen, 2009:51) atau seperangkat gagasan (teori) yang saling terkait tentang bagaimana suatu fenomena berfungsi atau terkait dengan bagian-bagiannya (Svinicki, 2010:5) atau suatu sistem konsep, asumsi, ekspektasi, keyakinan, dan teori-teori yang mendukung dan menginformasikan penelitian (Yamauchi, Ponte, Ratliffe, Traynor, 2017:11) atau teori tentatif tentang fenomena apa yang sedang dan mengapa terjadi (Maxwell, 2013:25) atau cara melihat permasalahan secara terintegrasi atau suatu hasil akhir dari berbagai konsep atau seperangkat 


\section{CAPTURE}

konsep terkait (Imenda, 2014:189) atau model terhadap relasi diantara variabel yang menyiratkan suatu perspektif teoretis tertentu untuk menggambarkan fenomena (Yamauchi, Ponte, Ratliffe, Traynor, 2017:11).

\subsubsection{Kerangka Konseptual bagi Peneliti dan Penelitian}

Kerangka penelitian bermanfaat bagi peneliti. Pertama, kerangka berguna untuk mengkhususkan siapa dan apa yang akan diteliti. Dalam hal ini kerangka membantu memfokuskan penelitian. Kedua, kerangka mengasumsikan beberapa keterhubungan. Keterhubungan secara logis atau mencerminkan temuan empiris. Kerangka membantu peneliti dalam mengumpulkan informasi secara selektif (Miles and Huberman, 1994:19).

Mengapa kerangka konseptual selalu menjadi isue penting dalam penelitian? Karena kerangka konseptual adalah titik pandang, titik pijak, dan jiwa dari setiap penelitian (Imenda, 2014:185). Setiap orang memiliki kerangka konseptual tentang bagaimana realitas bekerja yang melaluinya dapat digunakan membuat prediksi tentang bagaimana hubungan satu hal dengan hal lain dan apa yang akan terjadi ketika keduanya berinterseksi (Svinicki, 2010:5).

Kerangka konseptual selalu dikonstruksikan oleh peneliti yang mencerminkan pemikiran seluruh proses penelitian. Peneliti memiliki kebebasan dalam mengadopsi kerangka yang ada, tetapi harus memodifikasinya agar sesuai dengan sifat konteks penelitiannya demikian juga sifat pertanyaan penelitiannya (Adom, Hussein and Agyem, 2018:439). Kerangka konseptual disusun oleh dan menjadi tugas peneliti dalam merepresentasikan sudut pandangnya tentang dunia agar orang lain dapat menanggapinya secara akurat dan menyeluruh (Patton, 2002:21).

Kerangka konseptual menawarkan banyak keuntungan bagi peneliti. Karena membantu peneliti dalam mengidentifikasi dan mengkonstruksikan sudut pandangnya tentang fenomena yang diteliti. Cara bagaimana peneliti mempresentasikan pemecahan masalah yang telah ditentukan. Mengaksentuasi pemikiran mengapa topik penelitian layak diteliti, asumsi peneliti, pendekatan penelitian. Kerangka konseptual digunakan peneliti bilamana teori yang ada tidak aplikatif atau kurang memadai dalam menciptakan struktur penelitian (Adom, Hussein and Agyem, 2018:439). Kerangka konseptual menentukan bagaimana peneliti merumuskan permasalahan penelitian, bagaimana melaksanakan penelitian, dan apa makna yang dilekatkan pada data yang diperoleh dari penelitian (Imenda, 2014:185). Kerangka konseptual terkait dengan data (Strauss and Corbin, 1991:213), analisis (Krippendorff, 2004: 290), keaslian, kredibilitas, keakuratan, dan 
keterwakilan dokumen yang dipilih (Bowen, 2009: 33).

\subsection{Elemen-elemen Kerangka}

Konseptual Penelitian

Kerangka filosofi atau paradigma menyediakan panduan bagi pendekatan penelitian (Mertens, 2012:255). Oleh karena itu seorang peneliti harus memiliki pemahaman mendalam tentang suatu konsep dengan mengidentifikasi asumsi yang menjadi dasar penelitiannya (Neuman, 2007:28).

Pilihan metodologi penelitian harus sesuai dengan ontologi dan epistemologi (Guba and Lincoln, 1994: 109). Asumsi metodologi berhubungan dengan proses membangun dan menilai kerangka konseptual (Jabareen, 2009:51).

\subsubsection{Teori sebagai elemen kerangka konseptual}

Kerangka konseptual diperlukan ketika teori yang ada tidak aplikatif atau kurang memadai dalam menciptakan struktur penelitian (Adom, Hussein and Agyem, 2018:439). Kerangka konseptual dibangun melalui elemen-elemen pembentuknya. Elemen pembentuk kerangka konseptual mencakup: teori, konsep, deskripsi, dan bagan.

Teori dan empiris sebagai masukan penting bagi penyusunan kerangka konseptual (Miles and Huberman, 1994:22). Dalam hal ini, peneliti perlu mengkategorisasi dan menggambarkan konsep terkait dan memetakan relasi diantara konsep tersebut. Peneliti kualitatif menggunakan teori relevan dan penelitian empiris untuk mengorganisasikan kerangka konseptual, menyempurnakan atau mengkualifikasi kontradiksi (Miles and Huberman, 1994:22).

Terdapat kesalahpahaman jika penelitian kualitatif tidak memerlukan teori. Sulit dibayangkan jika sebuah penelitian tidak memiliki kerangka teoretis atau konseptual (Merriam, 1998:45). Kerangka teori berasal dari konsep, istilah, definisi, model, dan teori dari suatu literatur dan orientasi keilmuan tertentu (Merriam, 1998:46).

Teori adalah seperangkat konstruk, definisi, dan proposisi saling terkait yang mempresentasikan pandangan sistematis melalui relasi tertentu di antara variabel dengan tujuan menjelaskan dan memprediksi fenomena (kerlinger, 1986:9) atau seperangkat konsep terkait yang membentuk pandangan sistematis guna menjelaskan atau memprediksi fenomana. teori menggambarkan elemen-elemen dan relasi elemen satu dengan elemen lain. Karena sebuah teori menggambarkan konsep yang membentuknya dan relasi konsep satu dengan konsep lainnya (Lieher and Smith, 1999:8).

Teori memiliki tiga karakteristik utama, yakni: (a) seperangkat proposisi yang saling terkait, konsep dan definisi yang mempresentasikan sudut pandang 


\section{CAPTURE}

sistematis; (b) relasi khusus antar konsep; dan (c) menjelaskan dan/atau membuat prediksi tentang kejadian peristiwa berdasar relasi tertentu (Imenda, 2014:188).

Aplikasi teori dalam penelitian kualitatif mencakup tiga hal pokok, yakni: (1) teori dari paradigma dan metode penelitian, (2) bangunan teori sebagai hasil pengumpulan data, dan (3) teori sebagai kerangka kerja untuk memandu penelitian (Collins and Stockton, 2018:4). Sedangkan teori dalam kerangka konseptual diperlukan oleh peneliti karena: (1) menyediakan lensa dalam melihat permasalahan dan isu-isu sosial yang kompleks, (2) memfokuskan aspek-aspek data yang berbeda, (3) melakukan analisis (Reeves, Albert, Kuper, and Hodges, 2008:631), dan (4) menjadi struktur menyeluruh atau kerangka dalam memahami pengamatannya (Yamauchi, Ponte, Ratliffe, Traynor, 2017:11).

\subsubsection{Konsep sebagai elemen kerangka konseptual}

Konsep adalah blok bangunan dari teori. Konsep memiliki dua bagian, yakni sebuah simbol kata atau istilah dan sebuah definisi. Sebuah konsep adalah adalah suatu gagasan yang diekspresikan melalui simbol atau kata (Neuman, 2007:26) atau representasi citra atau simbol dari suatu gagasan abstrak (Lieher and Smith, 1999:7) atau komponen teori yang menyampaikan gagasan abstrak dalam suatu teori atau formulasi pengalaman mental kompleks (Chinn and Kramer, 1999:252).

Konsep mengandung asumsi bawaan. Konsep dan teori dibangun berdasarkan asumsi tentang sifat manusia, realitas sosial, atau fenomena tertentu. Untuk memperdalam pemahaman peneliti perlu mengidentifikasi asumsi terhadap konsep yang menjadi dasarnya (Neuman, 2007:28) atau seperangkat konsep terkait yang digunakannya (Imenda, 2014:189).

\subsubsection{Langkah-langkah Penyusunan Kerangka Konseptual Tahap Pertama: Tinjauan pustaka}

Semua penelitian empirik, apakah dengan metode kuantitatif, metode kualitatif ataupun metode gabungan, selalu berkait dengan pustaka atau konsep yang mendukung penelitian, berkait dengan tujuan penelitian, dan berkait dengan penelitian terdahulu (Rocco and Plakhotnik, 2009:120).

Tinjauan pustaka memiliki peran penting dalam penyusunan kerangka konseptual, demikian juga sebaliknya kerangka konseptual memiliki peran penting dalam menentukan tinjauan pustaka. Tinjauan pustaka dilakukan untuk mengembangkan kerangka konseptual atau menggali topik penelitian (Merriam and Simpson, 2000:10). Sebaliknya kerangka konseptual digunakan untuk menentukan tinjauan pustaka (Rocco and Plakhotnik, 2009:122).

$$
\text { Kerangka }
$$

konseptual 
menghubungkan berbagai konsep dan berfungsi sebagai dorongan untuk perumusan teori. Konsep-konsep yang digunakan dalam kerangka penelitian berasal dari berbagai pustaka (teori) relevan yang kemudian disintesiskan oleh peneliti (Bowen, 2006:3-4).

Tinjauan pustaka dalam kerangka konseptual memiliki lima fungsi, yakni: (1) membangun fondasi, (2) memperkaya pengetahuan, (3) mengkonseptualisasikan penelitian, (4) menilai rancangan dan instrumen penelitian, dan (5) menyediakan titik rujukan bagi interpretasi temuan (Rocco and Plakhotnik, 2009:122). Dalam membangun fondasi peneliti memerlukan hasil-hasil karya terdahulu untuk menunjukkan keterkaitan, menggambarkan kecenderungan, dan menyediakan ringkasan dari suatu konsep, teori, atau literatur. Untuk memperkaya pengetahuan peneliti menggunakan pustaka atau literatur untuk mempresentasikan pengetahuan dan kesenjangan yang ada dengan apa yang akan diteliti. Mengkonseptualisasi penelitian adalah menggambarkan hipotesis dan proposisi penelitian terdahulu, menetapkan istilah, dan menjelaskan asumsi dan limitasi karya relevan yang dikutip untuk membangun alasan penelitian. Temuan penelitian dapat dikomparasikan dengan dan berimplikasi terkait dengan penelitian terdahulu (Rocco and Plakhotnik, 2009:123).

Tahap Kedua: Penyusunan kerangka

\section{konseptual}

Metode penyusunan kerangka konseptul ini mengacu pada pemikiran Yoseph Jabareen. Menyusun kerangka konseptual dari berbagai bidang ilmu merupakan suatu proses teorisasi (Jabareen, 2009: 52).

Teks yang dipilih untuk analisis kerangka konseptual harus merepresentasikan relevansi fenomena dan literatur multidisiplin yang fokus pada fenomena yang diteliti secara efektif. Hal penting lainnya adalah bahwa teks harus merepresentasikan praktik terkait dengan fenomena. Oleh karena itu teks harus berasal dari beragam jenis, seperti buku, artikel, koran, esay, wawancara, dan praktik. Tiga aspek penting yang perlu diperhatikan oleh peneliti dalam menyusun kerangka konseptual, yakni: konsep, karakter penelitian, dan sumber data terpilih (Jabareen, 2009: 52 dan 57). Seperti telah disampaikan sebelumnya bahwa konsep adalah gagasan (Neuman, 2007:26) atau gagasan abstrak (Lieher and Smith, 1999:7) atau seperangkat konsep terkait (Imenda, 2014:189) sebagai komponen teori (Chinn and Kramer, 1999:252) atau blok bangunan dari teori (Neuman, 2007:28). Dalam hal ini peneliti perlu menetapkan dan mendefinisikan konsep-konsep yang relevan dengan penelitiannya.

Setiap konsep memiliki karakter atau asumsi bawaan (Neuman, 2007:28). 
Konsep-konsep yang digunakan peneliti dalam menyusun kerangka konseptualnya sesuai dengan asumsi ontologi, epistemologi, dan metodologinya. Dalam hal ini peneliti menetapkan dan mendefinisikan konsep secara ontologis, epistemologis, dan metodologis (Jabareen, 2009:57).

Sumber data terpilih adalah bagian penting dalam penyusunan kerangka konseptual. Peneliti perlu memetakan sumber data terpilih mana yang digunakan sebagai rujukan. Sumber data terpilih berasal dari teori dan pengalaman empiris merupakan rujukan penting dalam penyusunan kerangka konseptual (Miles and Huberman, 1994:22). Teori dan pengalaman empiris apa yang digunakan peneliti dalam menyusun kerangka konseptual menentukan bagaimana konsep-konsep didefinisikan dan apa asumsi filosofi yang dijadikan landasannya (Jabareen, 2009:57).

Berikut adalah langkah praktis penyusunan kerangka konseptual.

Pertama, memetakan sumber data terpilih. Memetakan spektrum literatur multidisiplin sesuai dengan fenomena yang dipermasalahkan. Proses ini mencakup identifikasi jenis teks dan sumber data lainnya, seperti data empirik dan praktik yang ada. Tinjauan teks multidisiplin secara ekstensif dan wawancara dengan praktisi, spesialis, dan sarjana dari berbagai disiplin yang fokus pada fenomena yang disasar.
Pengumpulan data harus komprehensif dan utuh serta mampu memfasilitasi pemetaan secara holistik dan valid (Jabareen, 2009: 53).

Kedua, membaca dan mengkategorisasi data terpilih. Membaca dan mengkategorisasi data baik melalui disiplin maupun skala kepentingan dan kuasa masing-masing disiplin. Proses ini memaksimalkan efektivitas penelitian dan menjamin representasi efektif masingmasing disiplin (Jabareen, 2009:54).

Ketiga, mengidentifikasi dan memberi nama konsep. Membaca dan membaca ulang data terpilih dan menemukan konsep.

Keempat, dekonstruksi dan kategorisasi konsep. Mendekonstruksi masing-masing konsep, mengidentifikasi atribut, karakteristik, asumsi, dan peran utamanya, dan mengorganisasi dan mengkategorisasi konsep sesuai dengan fitur dan ontologi, epistemologi, dan peran metodologinya. Hal yang penting dari fase ini adalah nama, deksripsi, dan kategorisasi masing-masing konsep sesuai dengan peran ontologi, epistemologi, atau metodologinya, serta menghadirkan rujukan untuk masing-masing konsep (Jabareen, 2009:54).

Kelima, mengintegrasi konsep. Mengintegrasikan dan mengelompokkan konsep-konsep bersama yang memiliki kesamaan ke dalam satu konsep baru. Mereduksi sejumlah konsep secara drastis 
dan memanipulasikannya ke dalam sejumlah konsep yang masuk akal.

Keenam, mensintesiskan dan meresintesiskan. Mensintesiskan konsepkonsep ke dalam suatu kerangka konseptual. Dalam hal ini peneliti dituntut keterbukaan, toleransi, dan fleksibilitanya dengan proses teorisasi dan munculnya teori baru. Proses ini iteratif dan sintesis berulang hingga peneliti memahami kerangka teoretis yang masuk akal. Peneliti harus mengetahui bagaimana membangun kerangka konseptualnya (Jabareen, 2009:54).

Ketujuh, memvalidasi kerangka konseptual. Validasi kerangka konseptual terkait dengan pertanyaannya apakah kerangka yang diajukan dan konsepkonsepnya masuk akal, bukan hanya bagi peneliti tetapi juga ilmuwan dan praktisi lain. Apakah kerangka menghadirkan teori yang masuk akal bagi ilmuwan yang meneliti fenomana dari disiplin yang berbeda?

Kedelapan, memikirkan kembali kerangka konseptual. Sebuah teori atau kerangka teori merepresentasikan fenomena multidisiplin akan selalu dinamis dan dapat direvisi sesuai dengan pemahaman, komentar, literatur baru, dll. Kerangka adalah multidiplin, teori harus masuk akal terhadap disiplin dan perspektif teoretis tentang fenomena tertentu dalam penelitian (Jabareen, 2009:55).

Tahap Ketiga: Penyajian kerangka konseptual

Penyajian grafis/diagram. Terkait dengan kerangka konseptual Miles dan Huberman menyarankan beberapa hal. Pertama, kerangka konseptual sebaiknya disusun dalam bentuk grafis, ketimbang dalam bentuk teks (Miles and Huberman, 1994:22).

Biasanya kerangka konseptual disusun melalui diagram untuk menjelaskan konstruk atau variabel dari topik penelitian dan keterkaitannya ditunjukkan melalui penggunaan tanda panah.

Penyajian deskripsi. Kerangka konseptual juga harus diekspresikan secara tertulis agar lebih mudah dipahami. Artinya, setelah peneliti membuat diagram, maka peneliti harus menjelaskan relasi diantaranya dan bagaimana kelengkapannya membantu menjawab permasalahan utama penelitian (Adom, Hussein and Agyem, 2018:439).

Penempatan. Kerangka konseptual menjadi bagian penting dari rencana atau proposal penelitian. Kerangka konseptual disajikan dalam bentuk diagram dan disertai penjelasan ditempatkan pada bagian akhir dari sub bagian tinjauan pustaka. Atau, ditempatkan pada sub bagian terpisah pada metode penelitian.

\section{SIMPULAN}

Kerangka konseptual adalah jejaring, yakni konsep saling terkait yang bersama-sama memberikan pemahaman 
komprehensif tentang suatu fenomena atau beberapa fenomena atau seperangkat gagasan (teori) yang saling terkait atau suatu sistem konsep, asumsi, ekspektasi, keyakinan, dan teori-teori yang mendukung dan menginformasikan penelitian atau teori tentatif tentang fenomena apa yang sedang dan mengapa terjadi atau cara melihat permasalahan secara terintegrasi atau suatu hasil akhir dari berbagai konsep atau seperangkat konsep terkait atau model terhadap relasi diantara variabel yang menyiratkan suatu perspektif teoretis tertentu untuk menggambarkan fenomena.

Kerangka penelitian sangat penting dalam setiap bidang penelitian, karena: (1) sebagai struktur dalam mengkonseptualisasikan dan merancang penelitian; (2) memahami seperangkat data; (3) mentransendensikan akal sehat; dan (4) memahami lebih mendalam; (5) merumuskan permasalahan penelitian; (6) membangun koherensi teoretis; (7) mengorganisasikan rencana dan implementasi penelitian; dan (8) mengkerangkakan simpulan konseptual.

\section{Kerangka konseptual selalu} menjadi isue penting dalam penelitian karena merupakan titik pandang, titik pijak, dan jiwa dari setiap penelitian. Setiap peneliti memiliki kerangka konseptual tentang bagaimana realitas bekerja yang melaluinya dapat digunakan membuat prediksi tentang bagaimana hubungan satu hal dengan hal lain dan apa yang akan terjadi ketika keduanya berinterseksi.

Kerangka konseptual disusun oleh dan menjadi tugas peneliti dalam merepresentasikan sudut pandangnya tentang dunia agar orang lain dapat menanggapinya secara akurat dan menyeluruh. Kerangka konseptual menawarkan banyak keuntungan bagi peneliti. Karena membantu peneliti dalam mengidentifikasi dan mengkonstruksikan sudut pandangnya tentang fenomena yang diteliti. Cara bagaimana peneliti mempresentasikan pemecahan masalah yang telah ditentukan. Mengaksentuasi pemikiran mengapa topik penelitian layak diteliti, asumsi peneliti, pendekatan penelitian. Kerangka konseptual digunakan peneliti bilamana teori yang ada tidak aplikatif atau kurang memadai dalam menciptakan struktur penelitian. Kerangka konseptual terkait dengan data, analisis, keaslian, kredibilitas, keakuratan, dan keterwakilan dokumen yang dipilih.

Kerangka konseptual diperlukan ketika teori yang ada tidak aplikatif atau kurang memadai dalam menciptakan struktur penelitian. Kerangka konseptual dibangun melalui elemen-elemen pembentuknya. Elemen pembentuk kerangka konseptual mencakup: teori, konsep, deskripsi, dan bagan.

Kerangka konseptual menghubungkan berbagai konsep dan berfungsi sebagai dorongan untuk perumusan teori. Konsep-konsep yang 
digunakan dalam kerangka penelitian berasal dari berbagai pustaka (teori) relevan yang kemudian disintesiskan oleh peneliti.

Kerangka konseptual sebaiknya disusun dalam bentuk grafis dilengkapi dengan penjelasan konstruk atau variabel dari topik penelitian dan keterkaitannya ditunjukkan melalui penggunaan tanda panah. Kerangka konseptual harus diekspresikan secara tertulis agar lebih mudah dipahami. Kerangka konseptual menjadi bagian penting dari rencana atau proposal penelitian. Kerangka konseptual yang disajikan dalam bentuk diagram dan penjelasan ditempatkan pada bagian akhir dari sub bagian tinjauan pustaka.

\section{DAFTAR ACUAN}

\section{Buku:}

Biggs, B. and Karlsson. H. (Ed.). 2011. The Routledge Companion to Research in the Arts, London and New York: Routledge.

Chinn, P.L. and Kramer, M.K. (Eds.). 1999. Theory and Nursing: A Systematic Approach. 5th Edition. St Louis: Mosby.

Crotty, M. 2003. The Foundations of Social Research: Meaning and Perspective in the Research Process. $3^{\text {rd }}$ ed. London: Sage Publication.

deMarris, K. and Lapan, S. D. (Eds.). 2004. Foundation for Research: Methods of Inquiry in Education and the Social Sciences. Mahwah, New Jersey, London: Lawrence Erlbaum Associate Publhisers.

Flick, U. 2010. An Introduction to Qualitative Research. Fourth Edition. London, Thousand Oaks, New Delhi,
Singapore: Sage Publications Ltd.

George, M. W. 2008. The Elements of Library Research: What Every Student Needs To Know, Princeton and Oxford: Princeton University Press.

Guba, E. G. and Lincoln, Y. S. 1994. "Competing Paradigms in Qualitative Research". In Denzin, N.K. and Lincoln. (Eds.). Handbook of Qualitative Research. Thousand Oaks: Sage Publication. (pp: 105117)

Guntur. 2016. Metode Penelitian Artistik. Surakarta: ISI Press.

Krippendor, K. 2004. Content Analysis: An Introduction to Its Methodology. Thousand Oaks, London, New Delhi: Sage Publications.

Kuhn, T. S. 1970. The Structure of Scientific Revolutions. $2^{\text {nd }}$ ed. Chicago: University of Chicago Press.

Merriam, S. B. 1998. Qualitative Research and Case Study Applications in Education. San Francisco: JosseyBass.

Merriam, S. B. and Simpson, E. L. (Eds.). 2000. A Guide to Research for Educators and Trainers of Adults. (Updated $2^{\text {nd }}$, Edition). Malabar, FL: Krieger.

Miles, M. B. and Huberman, A. M. (Eds.). (1994). Qualitative Data Analysis. Second Edition. Thousand Oaks, CA: Sage Publication.

Neuman, W. L. 2007. Basics of Social Research: Qualitative and Quantitative Approaches, Boston: Pearson Education, Inc.

O'Leary, Z. 2004. The Essential Guide to Doing Research. London, Thousand Oaks, New Delhi: Sage Publications.

Patton, M. 1990. Qualitative Evaluation and Research Methods. Sage: Newbury Park.

Somekh, B. and Lewin, C. (Eds.) 2005. 


\section{CAPTURE}

Research Methods in The Social Sciences, London, Thousand Oaks, New Delhi: Sage Publications.

Strauss, A. L. and Corbin, J. M. (Eds.). 1998. Basics of Qualitative Research: Techniques and Procedures for Developing Grounded Theory, Thousand Oaks, London, New Delhi: Sage Publications.

Turner, J. H. (Ed.). 2001. Handbook of Sociological Theory, New York: Springer.

\section{Jurnal IImiah:}

Berman, J. 2013. "Utility of a conceptual framework within doctoral study: A researcher's reflections". Issues in Educational Research, 23(1), 1-18. http://www.iier.org.au/iier23/berman.p $\mathrm{df}_{\text {. }}$

Bowen, G. A. 2006. "Grounded Theory and Sensitizing Concepts". International Journal of Qualitative Methods", 5(3), 12-23.

DOI: $10.1177 / 160940690600500304$.

Bowen, G. A. 2009. "Document Analysis as a Qualitative Research Method". Qualitative Research Journal, 9(2), 27-40. DOI:10.3316/QRJ0902027.

Collins, C. S. and Stockton, C. M. 2018. "The Central Role of Theory in Qualitative Research". International Journal of Qualitative Methods. 17(1), 1-10. DOI: $10.1177 / 1609406918797475$.

Jabareen, Y. "Building a Conceptual Framework: Philosophy, Definitions, and Procedure". International Journal of Qualitative Methods, 8(4), 2009: 49-62.

DOI: 10.1177/160940690900800406

Lester, Jr. Frank K. 2005. "On the theoretical, conceptual, and philosophical foundations for research in mathematics education". ZDM, 37(6), 457-467. DOI:10.1007/BF02655854.

Liehr, P. and Smith, M. J. 1999. "Middle range theory: Spinning research and practice to create knowledge for the new millennium." Advances in Nursing Science, 21(4), 81-91. DOI: 10.1097/00012272-19990600000011.

Lofland, J. H. 1974. "Styles of Reporting Qualitative Field Research," American Sociologist, 9(3), 101-111.

Mertens, D. M. 2012. "What Comes First? The Paradigm or the Approach?". Journal of Mixed Methods Research, 6(4), 255-257. DOI: $10.1177 / 1558689812461574$.

Reeves, S., Albert, M., Kuper, A., and Hodges, B. D. 2008. "Qualitative Research: Why use theories in qualitative research?". The British Medical Journal (BMJ). 337, 631634. DOI:10.1136/bmj.a949.

Rocco, T. S. and Plakhotnik, M. S. 2009. "Literature Reviews, Conceptual Frameworks, and Theoretical Frameworks: Terms, Functions, and Distinctions". Human Resource Development Review, 8(1), 120-130. DOI: $10.1177 / 1534484309332617$. 